Marquette University

e-Publications@Marquette

College of Nursing Faculty Research and

Publications

Nursing, College of

$3-1-2016$

Psychometric Evaluation of the Physical Activity Enjoyment Scale in Adults with Functional Limitations

Carolyn J. Murrock

University of Akron

Abir K. Bekhet

Marquette University, abir.bekhet@marquette.edu

Jaclene A. Zauszniewski

Case Western Reserve University

Accepted version. Issues in Mental Health Nursing, Vol. 37, No. 3 (March 2016): 164-171. DOI. (C) 2016 Taylor \& Francis. Used with permission. 


\title{
Psychometric Evaluation of the Physical Activity Enjoyment Scale in Adults with Functional Limitations
}

\author{
Carolyn J. Murrock \\ School of Nursing, University of Akron \\ Akron, $\mathrm{OH}$ \\ Abir Bekhet \\ College of Nursing, Marquette University \\ Milwaukee, WI \\ Jaclene A. Zauszniewski \\ Bolton School of Nursing, Case Western Reserve University \\ Cleveland, $\mathrm{OH}$
}

\begin{abstract}
Enjoyment is an important construct for understanding physical activity participation, and it has not been examined in adults with functional limitations. This secondary analysis reported the reliability and validity of the Physical Activity Enjoyment Scale (PACES) in a convenience sample of 40 adults with functional limitations. The participants completed the PACES, Center for Epidemiological Studies Depression Scale (CES-D), and the Late
\end{abstract}

Issues in Mental Health Nursing, Vol. 37, No. 3 (March 2016): pg. 164-171. DOI. This article is @ [Publisher's Name] and permission has been granted for this version to appear in e-Publications@Marquette. [Publisher] does not grant permission for this article to be further copied/distributed or hosted elsewhere without the express permission from [Publisher].] 
Life Function and Disability Instrument (LLFDI) prior to beginning a 12-week feasibility dance intervention study. Results indicated reliability as Cronbach's alpha was .95 and mean inter-item correlation was .52. To further support reliability, homogeneity of the instrument was evaluated using item-to-total scale correlations. Homogeneity was supported as all items had corrected item-to-total correlations greater than .30. For validity, the PACES was significantly related to only the Physical Function component of the LLFDI ( $r$ $=.38, p=.02$ ), but not the CES-D. Exploratory factor analysis revealed a 3factor structure that accounted for $73.76 \%$ of the variance. This feasibility intervention dance study represented the first attempt to examine the psychometric properties of the PACES in adults with functional limitations. The findings demonstrate support for the scale's reliability and validity among adults with functional limitations. Results are informative as further psychometric testing of the PACES is recommended using randomized clinical trials with larger sample sizes. Enjoyment for physical activity is an important construct for understanding physical activity participation in adults with functional limitations.

Functional limitations reflect real and perceptual restrictions of an adult's ability to effectively carry out activities needed to live independently in the community (Haley et al., 2002). In the United States, many adults live with various types of functional limitations and are at a greater risk for chronic diseases and adverse health outcomes and are more physically inactive than the general population (Carroll et al., 2014). Adults with functional limitations also are at greater risk for depression (Matthews et al., 2011), which is associated with disability, decreased physical function, and physical inactivity (Murrock \& Graor, 2014; Palmer, 2005). However, physical activity provides many physical and mental health benefits, including management of chronic diseases (Karingen, Dyskiv, \& Furnes, 2011; Nour, Laforest, Gauvin, \& Gignac, 2007), improved physical function and mobility (Baruth et al., 2011), and reduced depression (Murrock \& Graor, 2014). Given the health benefits of physical activity, there is a need to better understand how adults with functional limitations perceive physical activity participation and its impact on their health.

Enjoyment is a positive emotion linked to intrinsic motivation, meaning a behavior is performed strictly for the enjoyment it provides (Wankel, 1993). For a particular behavior, enjoyment consists of an affective response (pleasure, liking, and fun) and an individual's attitude and perceptions toward a particular behavior (pleasant/unpleasant, good/bad) (Kimiecik \& Harris, 1996). Enjoyment of physical activity is an individual's perception related to perceived

Issues in Mental Health Nursing, Vol. 37, No. 3 (March 2016): pg. 164-171. DOI. This article is @ [Publisher's Name] and permission has been granted for this version to appear in e-Publications@Marquette. [Publisher] does not grant permission for this article to be further copied/distributed or hosted elsewhere without the express permission from [Publisher].] 
competence and personal preference, which can be associated with the type of physical activity, intensity level, environmental conditions, competition, and whether the activity takes place in an individual or group format (Wankel, 1993). Consequently, individuals enjoy physical activity that evokes a positive affective response, brings about a good attitude, has personal meaning, and is available in a context that is appealing. Studies show enjoyment for physical activity is a key factor for adults (Graves et al., 2010; Hagberg, Lindahl, Nyberg, \& Hellenius, 2009; Hu, Motl, McAuley, \& Konopack, 2007; Mullen et al., 2011) and adults with multiple sclerosis (McAuley et al., 2007; Motl, Snook, McAuley, Scott, \& Douglass, 2006) to participate or drop out of physical activity programs. However, enjoyment for physical activity can change over time. What was enjoyable as a child (sports participation, competition, etc.) may not be enjoyable as an adult. Also, health-related goals for physical activity (weight loss, blood pressure control, blood sugar control, etc.) change over time and are often part of chronic disease management. Health-related goals are more extrinsically motivated and often not related to enjoyment (Wankel, 1993). Due to the importance of physical activity in adults with functional limitations, enjoyment is an important construct for understanding physical activity participation so that the anticipated physical and psychological benefits can be realized (Wankel, 1993). However, little is known about the construct of enjoyment for physical activity among adults with functional limitations.

The objective of this secondary analysis was to examine the reliability and validity of the Physical Activity Enjoyment Scale (PACES; Kendzierski \& DeCarlo, 1991) to measure enjoyment for physical activity in a sample of adults with functional limitations. This secondary analysis was from a feasibility study that documented the effects of a 12-week dance intervention on depression, physical function, and disability in adults with functional limitations (Murrock \& Graor, 2014). To extend the evidence, it was important to establish reliability and validity of the PACES in adults with functional limitations to determine their perception of enjoyment for physical activity.

Issues in Mental Health Nursing, Vol. 37, No. 3 (March 2016): pg. 164-171. DOI. This article is @ [Publisher's Name] and permission has been granted for this version to appear in e-Publications@Marquette. [Publisher] does not grant permission for this article to be further copied/distributed or hosted elsewhere without the express permission from [Publisher].] 
NOT THE PUBLISHED VERSION; this is the author's final, peer-reviewed manuscript. The published version may be accessed by following the link in the citation at the bottom of the page.

\section{Methods}

\section{Design, Setting, and Sample}

The feasibility intervention study recruited a convenience sample of residents living in a federally subsidized apartment complex located in an inner-city neighborhood in the Midwest (Murrock \& Graor, 2014). Residents of the apartment complex were classified as disabled and their income was at or below $60 \%$ of the median income for the county. Inclusion criteria were: (1) ability to read and write English and (2) provision of written medical clearance from their health care providers. Exclusion criteria were: (1) unstable chronic health conditions (unstable angina, uncontrolled hypertension, etc.), (2) foot ulcers, (3) currently enrolled in a structured exercise program 23 days per week, (4) diagnoses of psychoses or substance abuse, and (5) confinement to a wheelchair. Approval for the study protocol was obtained from the local university's Institutional Review Board (IRB).

\section{Sampling and Data Collection Procedures}

Participants were recruited via flyers posted in the community room and building entrance of the apartment complex. Over a 4-week period, 40 residents met inclusion criteria and were recruited for the study. Written informed consent was obtained from all participants included in the study prior the beginning of the dance intervention. The 12-week dance intervention was held in the community room in the apartment complex and taught by an African American woman. The dance routines were choreographed to secular and gospel music and many dance steps were modified to a lower intensity for those with overt physical limitations, such as pain, arthritis, or hip/knee discomfort (Murrock \& Graor, 2014). At baseline, demographics, medications, and health history were chronicled; comorbidity also was measured with the Charlson Scale, which used a weighted sum of comorbid conditions that mirror the functional burden of illness conditions (Charlson, Pompei, Alex, \& MacKenzie, 1987). The comorbid conditions included heart disease, peripheral vascular disease, stroke, shortness of breath, ulcers, diabetes, kidney disease, cancer, leukemia, liver disease, and immunodeficiency diseases. The PACES, Center for Epidemiological Studies Depression Scale (CES-D; Radloff,

Issues in Mental Health Nursing, Vol. 37, No. 3 (March 2016): pg. 164-171. DOI. This article is @ [Publisher's Name] and permission has been granted for this version to appear in e-Publications@Marquette. [Publisher] does not grant permission for this article to be further copied/distributed or hosted elsewhere without the express permission from [Publisher].] 
1977), and the Late Life Function and Disability Instrument (LLFDI; Haley et al., 2002; Jette et al., 2002) were assessed by self-reported questionnaires. Body fat and body mass index (BMI) were calculated by entering each participant's weight (in pounds), height (in inches), gender, and age into the segmental bioelectrical impedance analyzer (Omron Body Fat Analyzer, Model HBF-306, Bannockburn, IL). Each participant's hands and fingers gripped the sensor electrodes on the handles of the device while standing with arms extended. The arm-toarm analyzer is comparable to hydrostatic weighing and has a high validity coefficient $(r=.83$ ) (Gibson, Heyward, \& Mermier, 2000). Only baseline measures of PACES were analyzed because the dance intervention was proposed to have a direct effect on enjoyment, depression, and physical function.

\section{Measures}

The Physical Activity Enjoyment Scale (PACES; Kendzierski \& DeCarlo, 1991) is an 18-item scale that assesses enjoyment for physical activity by asking participants to rate "how you feel at the moment about the physical activity you have been doing" using a 7point bipolar Likert scale, from 1 (I enjoy it) to 7 (I hate it). Eleven items were negatively worded and seven items were positively worded. After reverse scoring the 11 negatively worded items, an overall enjoyment for physical activity score is determined by summing the items, with a range of 18-126 being possible. Higher scores indicate higher enjoyment. Cronbach's alpha has been reported as .96 (Motl et al., 2001). The PACES has reported reliability in children (Motl et al., 2001), college students (Hu et al., 2007; Kendzierski \& DeCarlo, 1991), adults (Graves et al., 2010; Heesch, Masse, \& Dunn, 2006; Mullen et al., 2011), and adults with multiple sclerosis (McAuley et al., 2007; Motl et al., 2006).

The Center for Epidemiological Studies Depression Scale (CESD; Radloff, 1977) measures self-reported symptoms of depression in the last week and contains 20 items that are scored on a 4-point Likert scale from 0 (rarely) to 3 (most of the time). A total score was calculated by summing the item scores. Scores range from 0 to 60 with higher scores indicating more depressive symptoms. As a screening tool for depression, scores of 11-15 indicate subthreshold

Issues in Mental Health Nursing, Vol. 37, No. 3 (March 2016): pg. 164-171. DOI. This article is (C) [Publisher's Name] and permission has been granted for this version to appear in e-Publications@Marquette. [Publisher] does not grant permission for this article to be further copied/distributed or hosted elsewhere without the express permission from [Publisher].] 
depression, scores of 16-22 indicate possible depression, and scores 23 and higher indicate probable depression. The CES-D has reported Cronbach's alpha of 0.90 and documented validity in older adults (Milette, Hudson, Baron, \& Thombs, 2010). The CES-D score was used to assess discriminant validity of the PACES.

The Late Life Function and Disability Instrument (LLFDI) consisted of two components: physical function and disability (Haley et al., 2002; Jette et al., 2002). The Physical Function component of the LLFDI assessed an individual's ability to perform gross and fine motor skills that are necessary for an assortment of activities relevant to living independently in the community (Haley et al., 2002). These activities consisted of carrying, moving, manipulating objects, and maintaining and changing body positions. The Physical Function component evaluated difficulty in performing 32 physical tasks in three dimensions (upper, lower, and advanced lower extremity) on a Likert scale from 1 (cannot do) to 5 (none) for each item (Haley et al., 2002). Scoring for the Physical Function component was computed by summing the item scores to obtain raw scores that were transformed to scaled scores (0-100) based on a 1-parameter Rasch model (Haley et al., 2002). Higher scores indicate higher levels of physical function. The Physical Function component has a Cronbach's alpha of .83-.96 and documented validity (Hand, Richardson, Letts, \& Stratford, 2010; Murrock \& Zauszniewski, 2011).

The Disability component of the LLFDI assessed an individual's performance of socially defined life tasks expected of an individual within a sociocultural and physical environment (Jette et al., 2002). Life tasks include personal maintenance; mobility; social, community, and civic activities; paid or volunteer work; and management of personal finances. The Disability component evaluated limitations in and frequency of performing 16 major life tasks. The limitation dimension has Likert response options from 1 (completely limited) to 5 (not at all limited), and the frequency dimension has Likert response options from 1 (never) to 5 (very often). Scoring for the Disability component was computed by summing the item scores to obtain raw scores that were transformed to scaled scores (0-100) based on a 1parameter Rasch model (Jette et al., 2002). Higher scores indicate less limitation and more frequency in performing tasks. The Disability

Issues in Mental Health Nursing, Vol. 37, No. 3 (March 2016): pg. 164-171. DOI. This article is @ [Publisher's Name] and permission has been granted for this version to appear in e-Publications@Marquette. [Publisher] does not grant permission for this article to be further copied/distributed or hosted elsewhere without the express permission from [Publisher].] 
NOT THE PUBLISHED VERSION; this is the author's final, peer-reviewed manuscript. The published version may be accessed by following the link in the citation at the bottom of the page.

component has a Cronbach's alpha of .84 (frequency) and .92 (limitations) (Karp et al., 2009) and documented validity (Meltzer, Kurz, Sarid, \& Jette, 2007). Both the Physical Function and Disability scores of the LLFDI were used to assess criterion-related validity as the ability to be physically active is influenced by physical function and disability.

\section{Data Analysis}

The IBM SPSS statistical package (version 23.0) computed reliability estimation using Cronbach's alpha and factor analysis to assess construct validity of the PACES. Reliability estimation for the PACES was based on internal consistency reliability using Cronbach's alpha with an alpha coefficient of greater than or equal to .70 (Nunnally \& Bernstein, 1994). Cronbach's alpha is sample specific as it measured internal consistency for test responses from the current sample of adults with functional limitations. To further support reliability in this sample of adults with functional limitations, homogeneity of the instrument was evaluated using item-to-total scale correlations. Homogeneity is supported when a substantial number of items have corrected item-to-total correlations greater than .30 (Field, 2005).

Validity was determined by assessing correlations with CES-D and LLFDI. Since age, obesity, and comorbidity influence enjoyment for physical activity, these variables also were included. An exploratory factor analysis (EFA) using principal components analysis with varimax rotation was conducted to explore underlying factors present in the PACES that were specific to the sample of adults with functional limitations (DeVon et al., 2007). EFA provided a preliminary analysis of how the PACES measured the construct of enjoyment and provided information on item performance and loadings across factors. In addition, EFA allowed all items to load on all factors and did not force any factor loading to be zero (DeVellis, 1991). Eigenvalues of one or greater determined the number of factors, and factor loadings of .40 and greater were considered good (Nunnally \& Bernstein, 1994). Due to the feasibility study's small sample size, steps were taken to assure adequate sample size prior to conducting EFA, using the Kaiser-Meyer-

Issues in Mental Health Nursing, Vol. 37, No. 3 (March 2016): pg. 164-171. DOI. This article is @ [Publisher's Name] and permission has been granted for this version to appear in e-Publications@Marquette. [Publisher] does not grant permission for this article to be further copied/distributed or hosted elsewhere without the express permission from [Publisher].] 
NOT THE PUBLISHED VERSION; this is the author's final, peer-reviewed manuscript. The published version may be accessed by following the link in the citation at the bottom of the page.

Olkin (KMO) Measure of Sampling Adequacy and Bartlett's Test of Sphericity.

\section{Results}

The convenience sample of 40 participants had an age range of 45-87 years, with a mean age of 63 years $(S D=7.9)$, BMI of 33.4 $(S D=7.8)$, and comorbidity of $2.3(S D=2.4)$ (see Table $\underline{1})$. The sample was $92 \%$ female and $75 \%$ African American with $40 \%$ of the participants identifying as divorced and $32.5 \%$ that had at least a high school education. None of the participants reported being enrolled in a structured exercise program 2-3 days per week. In addition, 50\% of the participants reported pain in their legs when walking, 38\% selfreported taking antidepressants/anti-anxiety medications, and $73 \%$ reported a history of hypertension. At baseline, enjoyment for physical activity scores $(M=99.4, S D=20.7)$ indicated moderate enjoyment, and depression scores $(M=19.9, S D=12.4)$ indicated possible depression. The physical function $(M=56.6, S D=11.2)$, disability frequency $(M=51.1, S D=10.9)$ and disability limitation scores $(M=$ $65.7, S D=14.9)$ showed that participants reported overt reductions in physical function, disability frequency, and disability limitations.

TABLE 1 Mean scores for PACES, CES-D, LLFDI-Physical function, LLFDIDisability frequency, LLFDI-Disability limitations, age, BMI, and Charlson Scale.

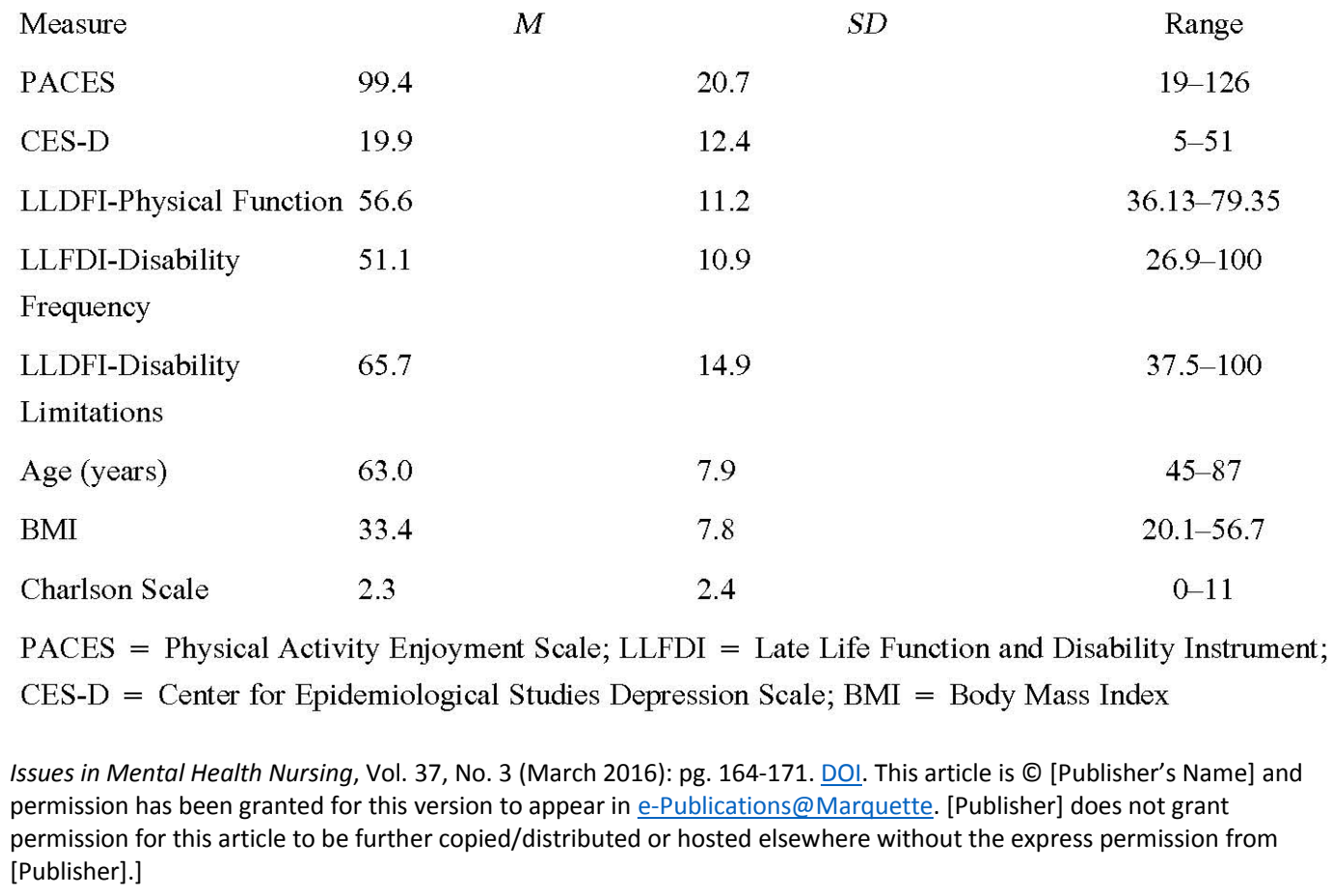


NOT THE PUBLISHED VERSION; this is the author's final, peer-reviewed manuscript. The published version may be accessed by following the link in the citation at the bottom of the page.

\section{Reliability}

The results indicated that the PACES was reliable; internal consistency was supported with a Cronbach's alpha of .95 and the mean inter-item correlations was .52. Further, Cronbach's alpha for the CES-D scale was .91; for the Physical Function component of the LLFDI it was .96, for the Disability Frequency component of the LLFDI it was .88, and for the Disability Limitations component of the LLFDI it was .93. Thus, all instruments demonstrated acceptable Cronbach's alpha in this sample of adults with functional limitations. To support homogeneity, all items had item-to-total correlation coefficients greater than .30 (Table 2). Reliability also was examined via inter-item correlations that should fall between .30 to .70 (Nunnally \& Bernstein, 1994). Of the 154 possible inter-item correlations, 124 inter-item correlations $(81 \%)$ fell within the desired range. Twenty inter-item correlations were greater than .70, which was indicative of redundancy, and 10 inter-item correlations were below the minimum criterion of .30. Finally, the mean inter-item correlations for the18item scale was .52 (range .17-.89).

TABLE 2 The PACES item analysis and factor analysis $(N=40)$.

Issues in Mental Health Nursing, Vol. 37, No. 3 (March 2016): pg. 164-171. DOI. This article is @ [Publisher's Name] and permission has been granted for this version to appear in e-Publications@Marquette. [Publisher] does not grant permission for this article to be further copied/distributed or hosted elsewhere without the express permission from [Publisher].] 
NOT THE PUBLISHED VERSION; this is the author's final, peer-reviewed manuscript. The published version may be accessed by following the link in the citation at the bottom of the page.

\begin{tabular}{|c|c|c|c|c|c|c|}
\hline & & & & & Item to Total & \\
\hline & & & Alpha if & & Scale & Communality \\
\hline Item & & & Deleted & & Correlations & Values \\
\hline 1 & I enjoy it/I hate it & .94 & & .73 & & .68 \\
\hline 2 & $\begin{array}{l}\text { I feel bored/I feel } \\
\text { interested }\end{array}$ & .95 & & .51 & & .71 \\
\hline 3 & I dislike it/I like it & .94 & & .70 & & .87 \\
\hline 4 & $\begin{array}{l}\text { I find it pleasurable/I } \\
\text { find it unpleasurable }\end{array}$ & .94 & & .72 & & .66 \\
\hline 5 & $\begin{array}{l}\text { I am very engaged in } \\
\text { this activity/I am not } \\
\text { engaged }\end{array}$ & & & .64 & & .84 \\
\hline 6 & $\begin{array}{l}\text { It's no fun at all/It's a } \\
\text { lot of fun }\end{array}$ & .94 & & .82 & & .79 \\
\hline 7 & $\begin{array}{l}\text { I find it energizing/I } \\
\text { find it tiring }\end{array}$ & .94 & & .75 & & .80 \\
\hline 8 & $\begin{array}{l}\text { It makes me } \\
\text { depressed/It makes } \\
\text { me happy }\end{array}$ & .94 & & .67 & & .72 \\
\hline 9 & $\begin{array}{l}\text { It's very pleasant/It's } \\
\text { very unpleasant }\end{array}$ & .94 & & .75 & & .71 \\
\hline 10 & $\begin{array}{l}\text { I feel good } \\
\text { physically/I feel bad } \\
\text { physically }\end{array}$ & .94 & & .81 & & .85 \\
\hline 11 & $\begin{array}{l}\text { It's very } \\
\text { invigorating/It's not } \\
\text { invigorating }\end{array}$ & .94 & & .78 & & .80 \\
\hline 12 & $\begin{array}{l}\text { I am very frustrated } \\
\text { by it/I'm not at all } \\
\text { frustrated } \\
\text { by it }\end{array}$ & .95 & & .53 & & .62 \\
\hline 13 & $\begin{array}{l}\text { It's very } \\
\text { gratifying/It's not at } \\
\text { all gratifying }\end{array}$ & .94 & & .86 & & .86 \\
\hline 14 & $\begin{array}{l}\text { It's very } \\
\text { exhilarating/It's not } \\
\text { at all exhilarating }\end{array}$ & .94 & & .72 & & .70 \\
\hline
\end{tabular}

Issues in Mental Health Nursing, Vol. 37, No. 3 (March 2016): pg. 164-171. DOI. This article is (C [Publisher's Name] and permission has been granted for this version to appear in e-Publications@Marquette. [Publisher] does not grant permission for this article to be further copied/distributed or hosted elsewhere without the express permission from [Publisher].] 
NOT THE PUBLISHED VERSION; this is the author's final, peer-reviewed manuscript. The published version may be accessed by following the link in the citation at the bottom of the page.

15

16

17

18

$$
\begin{aligned}
& \text { It's not at all } \\
& \text { stimulating/It's very } \\
& \text { stimulating }
\end{aligned}
$$

.95

Strong sense of

accomplishment/No

sense of

accomplishment

It's very

.94

refreshing/It's not at

all refreshing

Would rather be

.95

doing something

else/Would

rather be doing

nothing else
.59

.78

.78

\section{Validity}

For criterion-related validity, the PACES was significantly related to the Physical Function component of the LLFDI $(r=.38, p=.02)$, although it was a weak to moderate correlation. This meant that higher physical function resulted in higher enjoyment for physical activity. Interestingly, enjoyment for physical activity did not correlate with depression in this sample of adults with functional limitations.

However, there were significant inverse relationships between depression and physical function $(r=-.40, p=.01)$, disability frequency $(r=-.32, p=.04)$, and disability limitations $(r=-53, p$ $<.00)$. This meant that lower depression led to higher levels of physical function, more frequency in performing tasks, and less disability limitation. The PACES did not significantly correlate with the covariates of age, BMI, or comorbidity measured by the Charlson scale (see Table $\underline{3}$ ). 
TABLE 3 Correlations of PACES, CES-D, LLFDI-Physical function, LLFDIDisability frequency, LLFDI-Disability limitations, age, BMI, and Charlson Scale.

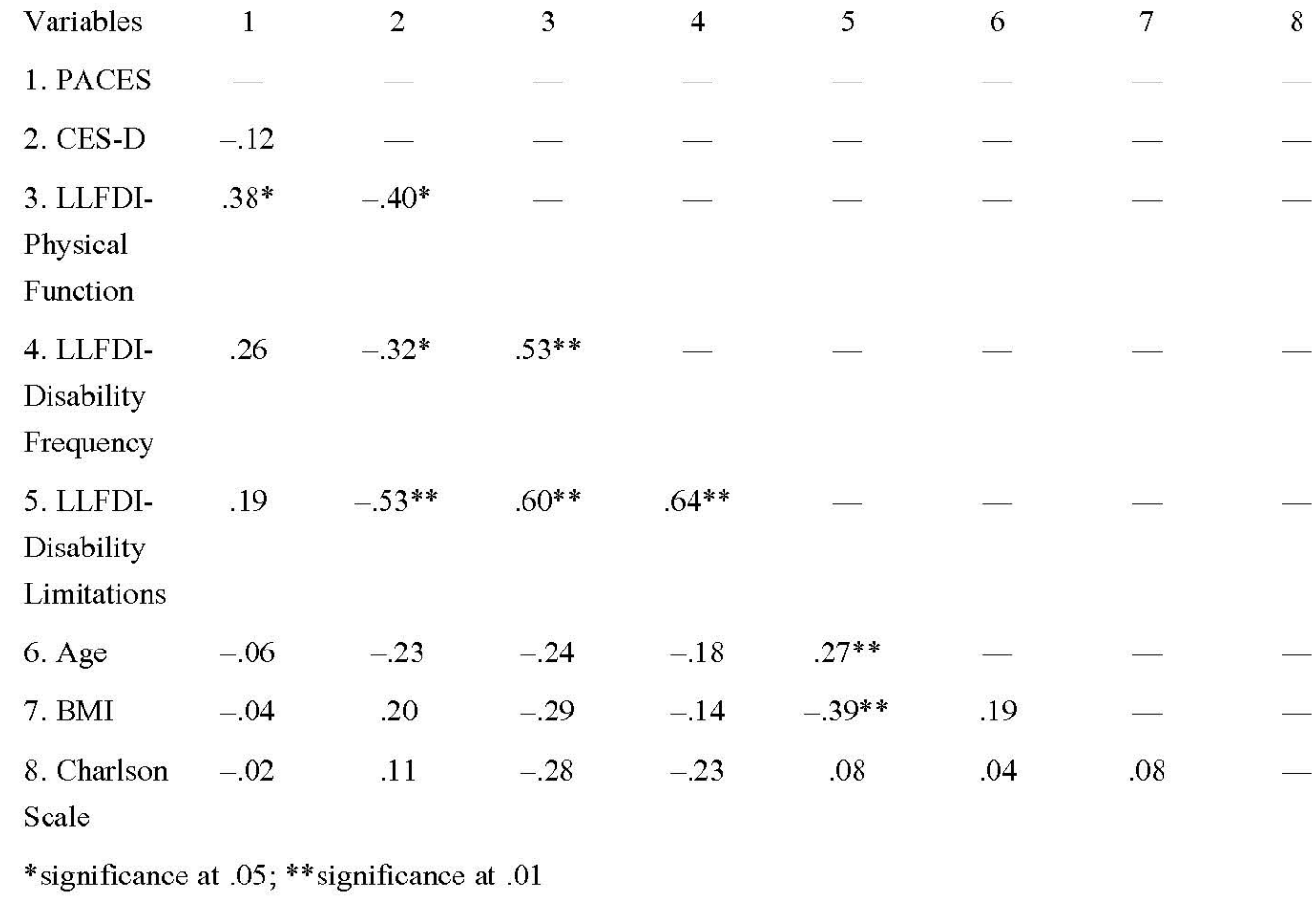

Prior to the extraction of the factors, two tests assessed the suitability of the data for factor analysis. The Kaiser-Meyer-Olkin (KMO) Measure of Sampling Adequacy is recommended when there is a small sample size and should be .50 or greater for factor analysis. The Bartlett's Test of Sphericity should be significant $(p<.05)$ for factor analysis to be suitable (DeVon et al., 2007). In this study, KMO was .79 and Bartlett's Test of Sphericity was $X^{2}=.664$, $\mathrm{df}=153$, and $p<.001$. Both measures established that the sample size of 40 was adequate to conduct EFA.

Exploratory factor analysis was examined by allowing all 18 items of the PACES to load on all factors without forcing any factor loadings. The analysis resulted in a 3-factor solution that accounted for $73.76 \%$ of the variance. The scree plot also confirmed a 3-factor solution. Twelve items loaded on factor one and accounted for $55.4 \%$ of the variance. Ten items loaded on factor two and accounted for $11.7 \%$ of the variance, and six items loaded on factor three and accounted for $6.5 \%$ of the variance. In addition, the eigenvalues for

Issues in Mental Health Nursing, Vol. 37, No. 3 (March 2016): pg. 164-171. DOI. This article is @ [Publisher's Name] and permission has been granted for this version to appear in e-Publications@Marquette. [Publisher] does not grant permission for this article to be further copied/distributed or hosted elsewhere without the express permission from [Publisher].] 
NOT THE PUBLISHED VERSION; this is the author's final, peer-reviewed manuscript. The published version may be accessed by following the link in the citation at the bottom of the page.

the factors were 9.98 (factor one), 2.11 (factor two), and 1.18 (factor three). Based on factor loadings of .40 or greater, it was interesting to note that nine items loaded on more than one factor; five items loaded on factors one and two, two items loaded on factors two and three, and one item loaded on factors one and three. Only one item loaded on all three factors (see Table $\underline{4}$ ).

TABLE 4 Items in each factor and factor loadings for the PACES $(N=40)$. 
NOT THE PUBLISHED VERSION; this is the author's final, peer-reviewed manuscript. The published version may be accessed by following the link in the citation at the bottom of the page.

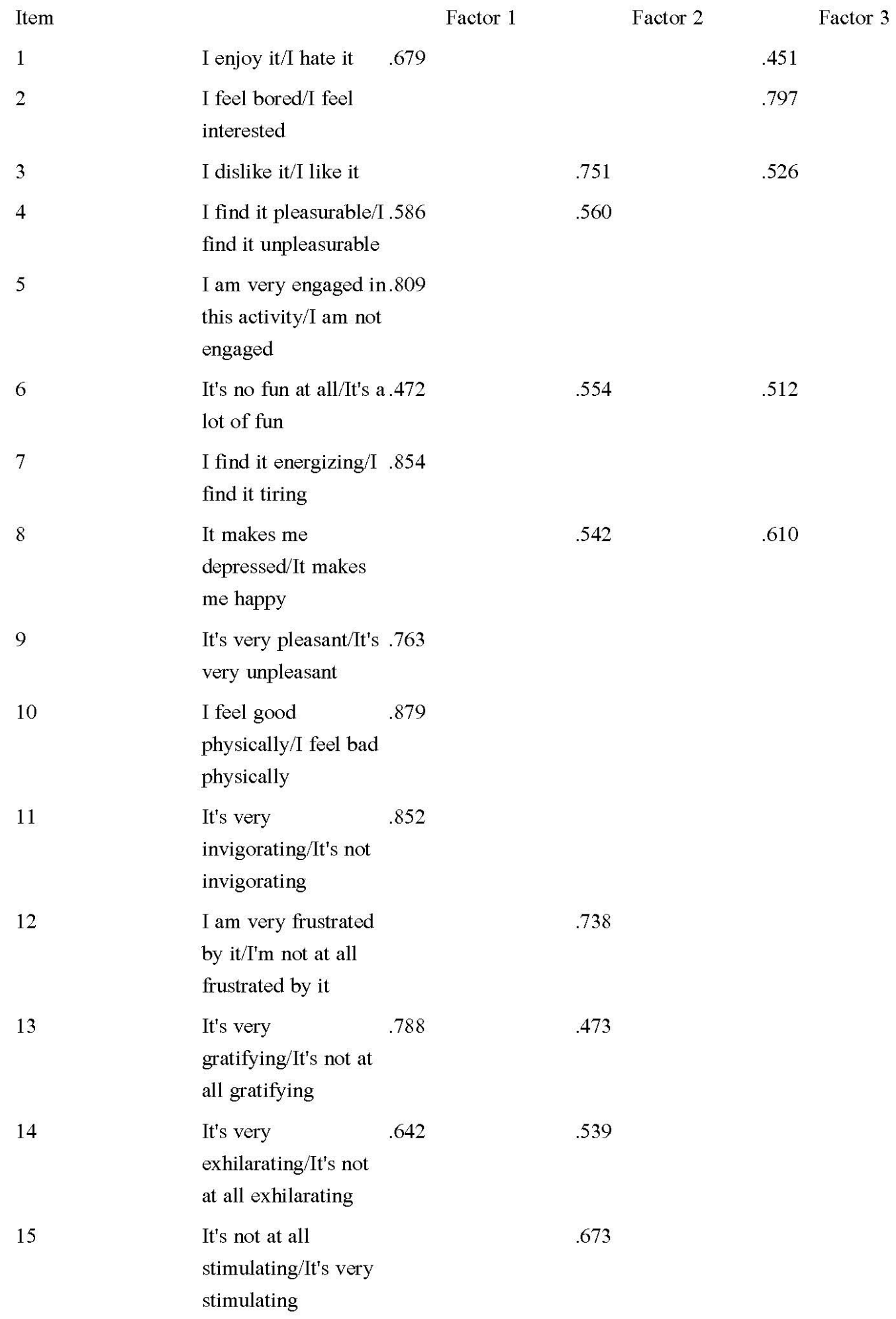


NOT THE PUBLISHED VERSION; this is the author's final, peer-reviewed manuscript. The published version may be accessed by following the link in the citation at the bottom of the page.

16

17

18

$\begin{array}{ll}\text { Strong sense of } & .646 \\ \text { accomplishment/no } & .502 \\ \text { accomplishment } & .628 \\ \text { It's very } & .600 \\ \text { refreshing/It's not at } & \\ \text { all refreshing } & \\ \text { Rather be doing } & \\ \text { something } \\ \text { else/Would rather be } \\ \text { doing nothing else } \\ \text { Activity Enjoyment Scale }\end{array}$

502

\section{Discussion}

This feasibility intervention study represents the first attempt to examine the reliability and the validity of the Physical Activity Enjoyment Scale (PACES) in adults with functional limitations. Reliability of the PACES was demonstrated through adequate estimates of internal consistency; Cronbach's alpha was .95, exceeding the minimum criterion of .70 (Nunnally \& Bernstein, 1994). This internal consistency estimate is similar to findings from previous studies of older adults ( $a=.93)$ (Mullen et al., 2011) and community-dwelling older adults $(a=.95)$ (Heesch et al., 2006). Homogeneity was supported by item-to-total correlations; all 18 items were greater than the recommended .30 (Field, 2005). As for the inter-item correlations, $81 \%$ fell within the acceptable range, which supported that the PACES measured the construct of enjoyment for physical activity in this sample of adults with functional limitations. Replication of this study in a large sample of adults with functional limitations is recommended.

Evidence for the construct validity of the PACES also was supported in this study of adults with functional limitations. The PACES significantly correlated with Physical Function component of the LLFDI, which evaluated an individual's ability to perform gross and fine motor skills important for living independently in the community (Haley et al., 2002). Thus, performing gross and fine motor skills, such as performing the dance steps and arm movements, was needed for enjoyment for physical activity of the dance intervention. However, the

Issues in Mental Health Nursing, Vol. 37, No. 3 (March 2016): pg. 164-171. DOI. This article is @ [Publisher's Name] and permission has been granted for this version to appear in e-Publications@Marquette. [Publisher] does not grant permission for this article to be further copied/distributed or hosted elsewhere without the express permission from [Publisher].] 
PACES did not correlate with either the Disability Frequency or Disability Limitations components of the LLFDI. The Disability components assessed an individual's performance of socially defined life tasks expected of an individual within a sociocultural and physical environment. For this study, performing socially defined life tasks was not related to enjoyment for physical activity of the dance intervention. Surprisingly, depression did not correlate with PACES, which could be due to the fact that many participants were taking antidepressant medications. Physical function and depression were included in the analysis due to their prevalence in adults with functional limitations and potential impact on enjoyment for physical activity. The results of this study extend the evidence since depression and physical function are other theoretical constructs that can influence enjoyment of physical activity in adults with functional limitations (Murrock \& Graor, 2014).

Exploratory factor analysis using principal components analysis with varimax rotation revealed a 3-factor structure. Both factors one and two predominantly measured an individual's attitude and perceptions towards dancing (engaged/not engaged; gratifying/not gratifying; stimulating/not stimulating). For factor one, it was interesting to note that 11 of the 12 items were negatively worded while factor two had five items that were negatively and five that were positively worded. Together, factors one and two explained $67.1 \%$ of the variance of the scale score. Factor three mostly measured affective response/emotion towards dancing (enjoy/hate; dislike/like; depressed/happy). Of the six items that loaded on factor three, five of the six items were positively worded. Overall, the 18 items of the PACES measured both affective responses and an individual's attitude and perceptions toward the particular behavior of dancing. However, since enjoyment is a positive emotion, it seemed that the negative or positive wording of each item had an impact on the participants' attitude and perceptions and affective response/emotion for dancing.

The 3-factor structure reported in this study is in contrast to other studies. For example, a unidimensional structure of the PACES has been reported in third graders (Moore et al., 2009) and in adolescent girls (Motl et al., 2001), while a 2-factor structure was documented in children with asthma (Roman, Pinillos, Martınez, \& Rus,

Issues in Mental Health Nursing, Vol. 37, No. 3 (March 2016): pg. 164-171. DOI. This article is @ [Publisher's Name] and permission has been granted for this version to appear in e-Publications@Marquette. [Publisher] does not grant permission for this article to be further copied/distributed or hosted elsewhere without the express permission from [Publisher].] 
2014). All three studies assessed the enjoyment for physical education class as the type of physical activity. A unidimensional structure also was reported in healthy community-dwelling adults that assessed enjoyment for physical activity for no specific type of physical activity (Heesch et al., 2006). In addition to an individual's attitude, perceptions, and affective response/emotion towards physical activity, enjoyment also depends upon an individual's perceived competence and physical activity preference as well as intensity, environment, and whether the activity is performed in an individual or group format. Hence, continued psychometric analysis of the PACES is warranted in both children and adult populations.

Results of this secondary analysis of the feasibility intervention study should be viewed with caution due to several limitations. Even though the Kaiser-Meyer-Olkin (KMO) Measure of Sampling Adequacy and the Bartlett's Test of Sphericity determined adequate sample size to conduct EFA, the small sample size impacts potential inferences about the PACES to other adults with functional limitations. Second, this study used a convenience sample of adults with functional limitations from one urban subsidized housing complex in the Midwest. Future studies should include more diverse samples of adults with functional limitations from various regions as different climates and rural areas may impact real and perceived functional limitations. Also, comparing the PACES to another instrument that measures enjoyment or some other positive emotion or affective response associated with physical activity will increase validity. Even with these limitations, the results are still informative as this feasibility study provides evidence of reliability and validity of the PACES in this vulnerable population. Further psychometric testing of the PACES is recommended using randomized clinical trials with larger sample sizes as enjoyment for physical activity is an important construct for understanding physical activity participation in adults with functional limitations.

Declaration of Interest: The authors report no conflicts of interest. The authors alone are responsible for the content and writing of the article.

\section{References}

1. Baruth, M., Wilcox, S., Wegley, S., Buchner, D. M., Ory, M. G., Phillips, A., ... Bazzarre, T. (2011). Changes in physical functioning in the active 
living every day program of the active for life initiative. International Journal of Behavioral Medicine, 18(2), 199-208. doi:10.1007/s12529010-9108-7

2. Carroll, D. D., Courtney-Long, E. A., Stevens, A. C., Sloan, M. L., Lullo, C., Visser, S. N., ... Dorn, J. M. (2014). Vital signs: Disability and physical activity-United States, 2009-2012. Morbidity and Mortality Weekly Report, 63(18), 407-413.

3. Charlson, M. E., Pompei, P., Alex, K. L., \& MacKenzie, C. R. (1987). A new method of classifying prognostic comorbidity in longitudinal studies: Development and validation. Journal of Chronic Diseases, 40, 373383.

4. DeVellis, R. F. (1991). Scale development: Theory \& applications. Newbury Park, CA: Sage.

5. DeVon, H. A., Block, M. E., Moyle-Wright, P., Ernst, D. M., Hayden, S. J., Lazzara, D. J., ... Kostas-Polston, E. (2007). A psychometric toolbox for testing validity and reliability. Journal of Nursing Scholarship, 39(2), 155-164.

6. Field, A. (2005). Discovering statistics using SPSS (2nd ed.). London, UK: Sage.

7. Gibson, A. L., Heyward, V. H., \& Mermier, C. M. (2000). Predictive accuracy of omron body logic analyzer in estimating relative body fat of adults. International Journal of Sport, Nutrition, and Exercise Metabolism, 10, 216-227.

8. Graves, L. E. F., Ridgers, N. D., Williams, K., Stratton, G., Atkinson, G., \& Cable, N. T. (2010). The physiological cost and enjoyment of Wii Fit in adolescents, young adults, and older adults. Journal of Physical Activity and Health, 7, 393-401.

9. Hagberg, L. A., Lindahl, B., Nyberg, L., \& Hellenius, M. L. (2009). Enjoyment of physical education influenced self-efficacy beliefs about PA and mediated the effect of the intervention: Importance of enjoyment when promoting physical exercise. Scandinavian Journal of Medicine Science and Sports, 19, 740-747. doi:10.1111/j.16000838.2008.00844.x

10. Haley, S. M., Jette, A., Coster, W. J., Kooyoomjian, J. T., Levensen, S., Heeren, T., \& Ashba, J. (2002). Late life function and disability instrument: II. Development and evaluation of the function component. Journals of Gerontology, Series A, Biological Sciences and Medical Sciences, 57A(4), M217-M222.

11. Hand, C., Richardson, J., Letts, L., \& Stratford, P. (2010). Construct validity of the late life function and disability instrument for adults with chronic conditions. Disability and Rehabilitation, 32(1), 50-56. doi: 10.3109/09638280902998789

Issues in Mental Health Nursing, Vol. 37, No. 3 (March 2016): pg. 164-171. DOI. This article is @ [Publisher's Name] and permission has been granted for this version to appear in e-Publications@Marquette. [Publisher] does not grant permission for this article to be further copied/distributed or hosted elsewhere without the express permission from [Publisher].] 
12. Heesch, K. C., Masse, L. C., \& Dunn, A. L. (2006). Using Rasch modeling to re-evaluate three scales related to physical activity: Enjoyment, perceived benefits and perceived barriers. Health Education Research, 21(Suppl 1), i58-i72. doi:10.1093/her/cyl054

13. Hu, L., Motl, R. W., McAuley, E., \& Konopack, J. F. (2007). Effects of selfefficacy on physical activity enjoyment in college-aged women. International Journal of Behavioral Medicine, 14(2), 92-96.

14. Jette, A., Haley, S. M., Coster, W. J., Kooyoomjian, J. T., Levenson, S., Heeren, T., \& Ashba, J. (2002). Late life function and disability instrument: I. Development and evaluation of the disability component. Journals of Gerontology, Series A, Biological Sciences and Medical Sciences, 57A(4), M209-M216.

15. Karingen, I., Dyskiv, E., \& Furnes, B. (2011). The elderly stroke patient's long-term adherence to physiotherapy home exercises. Advances in Physiotherapy, 13, 145-152. doi:10.3109/14038196.2011.619574

16. Karp, J. F., Skidmore, E., Lotz, M., Lenze, E., Dew, M. A., \& Reynolds, C. F. (2009). Use of the late-life function and disability instrument to assess disability in major depression. Journal of the American Geriatric Society, 57, 1612-1619. doi:10.1111/j.1532-5415.2009.02398.x

17. Kendzierski, D., \& DeCarlo, K. J. (1991). Physical activity enjoyment scale: Two validation studies. Journal of Sport and Exercise Psychology, 13, 50-64.

18. Kimiecik, J. C., \& Harris, A. T. (1996). What is enjoyment? A conceptual/definitional analysis with implications for sport and exercise psychology. Journal of Sport \& Exercise Psychology, 18(3), 247-263.

19. Matthews, M. M., Hsu, F. C., Walkup, M. P., Barry, L. C., Patel, K. V., \& Blair, S. N. (2011). Depressive symptoms and physical performance in the lifestyle interventions and independence for elders pilot study. Journal of the American Geriatrics Society 59, 495-500. doi:10.1111/j.1532-5415.2011.03319.x

20. McAuley, E., Motl, R. W., Morris, K. S., Hu, L., Doerksen, S. E., Elavsky, S., \& Konopack, J. F. (2007). Enhancing physical activity adherence and well-being in multiple sclerosis: A randomized controlled trial. Multiple Sclerosis, 13, 652-659.

21. Meltzer, I., Kurz, I., Sarid, O., \& Jette, A. (2007). Relationship between self-reported function and disability and balance performance measures in the elderly. Journal of Rehabilitation Research \& Development, 44(5), 685-692. doi:10.1682/JRRD.2006.10.0133

22. Milette, K., Hudson, M. A., Baron, M., \& Thombs, B. D. (2010). Comparison of the PHQ-9 and CES-D depression scales in systematic sclerosis: Internal consistency reliabiity, convergent validity and clinical correlates. Rheumatology, 49, 789-796. doi: $10.1093 /$ rheumatology/kep443

Issues in Mental Health Nursing, Vol. 37, No. 3 (March 2016): pg. 164-171. DOI. This article is @ [Publisher's Name] and permission has been granted for this version to appear in e-Publications@Marquette. [Publisher] does not grant permission for this article to be further copied/distributed or hosted elsewhere without the express permission from [Publisher].] 
23. Moore, J. B., Yin, Z., Hanes, J., Duda, J., Gutin, B., \& Barbeau, P. (2009). Measuring enjoyment of physical activity in children: Validation of the physical activity enjoyment scale. Journal of Applied Sport Psychology, 21(Suppl 1), S116-S129. doi:10.1080/10413200802593612

24. Motl, R. W., Dishman, R. K., Saunders, R., Dowda, M., Felton, G. M., \& Pate, R. R. (2001). Measuring enjoyment of physical activity in adolescent girls. American Journal of Preventive Medicine, 21(2), 110117.

25. Motl, R. W., Snook, E. M., McAuley, E., Scott, J. A., \& Douglass, M. L. (2006). Correlates of physical activity among individuals with multiple sclerosis. Annals of Behavioral Medicine, 32(2), 154-161.

26. Mullen, S. P., Olson, E. A., Phillips, S. M., Szabo, A. N., Wójcicki, T. R., Mailey, E. L., ... McAuley, E. (2011). Measuring enjoyment of physical activity in older adults: Invariance of the physical activity enjoyment scale (paces) across groups and time. International Journal of Behavioral Nutrition and Physical Activity, 8, 103. doi:10.1186/14795868-8-103

27. Murrock, C. J., \& Graor, C. (2014). Effects of dance on depression, physical function, and disability in underserved adults. Journal of Aging and Physical Activity, 22(3), 380-385.

http://dx.doi.Org/10.1123/JAPA.2013-0003">10.1123/JAPA.20130003

28. Murrock, C. J., \& Zauszniewski, J. A. (2011). Late Life Function and Disability Instrument in African American women: Function component. Women \& Health, 51(5), 482-496. doi:10.1080/03630242.2011.589493

29. Nour, K., Laforest, S., Gauvin, L., \& Gignac, M. (2007). Long-term maintenance of increased exercise involvement following a selfmanagement intervention for housebound older adults with arthritis. International Journal of Behavioral Nutrition and Physical Activity 4(22). doi: $10.1186 / 1479-5868-4-22$

30. Nunnally, J. C., \& Bernstein, I. H. (1994). Psychometric theory (3rd ed.). New York, NY: McGraw-Hill.

31. Palmer, C. (2005). Exercise as a treatment for depression in elders. Journal of the American Academy of Nurse Practitioners, 17(2), 60-66.

32. Radloff, L. S. (1977). The CES-D Scale: A self-report depression scale for research in the general population Applied Psychological Measurement, 1(3), 385-401.

33. Roman, P. A. L., Pinillos, F. G., Martınez, A. V. N., \& Rus, T. I. (2014). Validity and reliability of Physical Activity Enjoyment Scale questionnaire (PACES) in children with asthma. Journal of Asthma, 51(6), 633-638. doi:10.3109/02770903.2014.898773

Issues in Mental Health Nursing, Vol. 37, No. 3 (March 2016): pg. 164-171. DOI. This article is @ [Publisher's Name] and permission has been granted for this version to appear in e-Publications@Marquette. [Publisher] does not grant permission for this article to be further copied/distributed or hosted elsewhere without the express permission from [Publisher].] 
NOT THE PUBLISHED VERSION; this is the author's final, peer-reviewed manuscript. The published version may be accessed by following the link in the citation at the bottom of the page.

34. Wankel, L. (1993). The importance of enjoyment to adherence and psychological benefits from physical activity. International Journal of Sport Psychology, 24, 151-169.

Issues in Mental Health Nursing, Vol. 37, No. 3 (March 2016): pg. 164-171. DOI. This article is @ [Publisher's Name] and permission has been granted for this version to appear in e-Publications@Marquette. [Publisher] does not grant permission for this article to be further copied/distributed or hosted elsewhere without the express permission from [Publisher].] 